\title{
Simultaneous determination of chlorogenic acid, caffeic acid and caffeine in hydroalcoholic and aqueous extracts of Ilex paraguariensis by HPLC and correlation with antioxidant capacity of the extracts by DPPH. reduction
}

\author{
Diogo Pineda Rivelli, Vanessa Vitoriano da Silva, Cristina Dislich Ropke, Denise Varella Miranda, \\ Rebeca Leite Almeida, Tania Cristina Higashi Sawada, Silvia Berlanga de Moraes Barros*
}

Departamento de Análises Clínicas e Toxicológicas, Faculdade de Ciências Farmacêuticas, Universidade de São Paulo

*Correspondence:

S. B. M. Barros

Departamento de Análises Clínicas e Toxicológicas

School of Pharmaceutical Sciences University of São Paulo,

Av. Prof. Lineu Prestes, 580,

05508-000 - São Paulo - SP, Brazil

E-mail: smbarros@usp.br
A new high performance liquid chromatographic method has been established for simultaneous determination of chlorogenic acid, caffeic acid and caffeine in hydroalcoholic and aqueous extracts of Ilex paraguariensis. Analytical curves showed good linear regression in the concentration ranges $0.49-7.8 \mu \mathrm{g} / \mathrm{mL}$ for chlorogenic acid, 0.25-3.9 $\mu \mathrm{g} / \mathrm{mL}$ for caffeic acid and 0.244-7.8 $\mu \mathrm{g} / \mathrm{mL}$ for caffeine. Reduction of the DPPH radical was used to determine the antioxidant capacity of the extracts. Our method for the simultaneous determination of chlorogenic acid, caffeic acid and caffeine was highly sensitive, having lower detection and quantitation limits than other papers that used similar methodology.

\author{
Uniterms \\ - Chlorogenic acid \\ - Caffeic acid \\ - Caffeine \\ - Antioxidant \\ - DPPH \\ - Ilex paraguariensis
}

\section{INTRODUCTION}

A free radical is any chemical species capable of independent existence that contains one or more unpaired electrons (Halliwel, Gutteridge, 1999). The role of freeradical reactions in biology has become an area of intense interest. It is generally accepted that free radicals play an important role in the development of tissue damage and pathological events in living organisms (De Groot, Noll, 1987; Schinella et al., 2000). The consumption of plant foods is associated with a reduced risk of chronic diseases (cancer and cardiovascular), in part because of substances with antioxidant capacity, and those that modulate enzyme activity and gene expression (Day et al., 2004).

Antioxidative properties have been found in leaf infusions of yerba mate (Ilex paraguariensis) (Chandra, Mejia, 2004). Mate is a popular tea in South America, where it is frequently drunk instead of coffee as a stimulating drink. It is greenish in color and contains caffeine, tannins and several vitamins such as B1 (thiamine), B2 (riboflavin), B5 (pantothenic acid), C, E, $\beta$ carotene, sucrose, fructose, folic acid, trigonelline, choline and many polyphenolic compounds (flavonoids and chlorogenic acid) (Gugliucci, Stahl, 1995).

Much experimental work (in vivo and in vitro) has been performed to evaluate the antioxidant capacity of yerba mate. The leaf extract of I. paraguariensis was shown to be absorbed and to be active in vivo when healthy patients drank it, and one hour later blood was collected and the LDL content analysed in relation to lipid peroxidation (Gugliucci, 1996). The Ilex paraguariensis aqueous 
extract inhibited the lipid peroxidation induced by the $\mathrm{Fe}^{2+} /$ ascorbate system and that induced by the $\mathrm{CCl}_{4} / \mathrm{NADPH}$ system, in both cases detected by the thiobarbituric acid assay (Schinella et al., 2000)

For the simultaneous determination of CGA (chlorogenic acid) and CFA (caffeic acid) (Figure 1) by HPLC, various sets of chromatographic conditions have been used in recent work: in Li et al. (2004), the mobile phase was a mixture of methanol and $0.2 \mathrm{~mol} / \mathrm{L}$ acetate buffer ( $\mathrm{pH} 3.6)(15: 85, \mathrm{v} / \mathrm{v})$ flowing at $1.0 \mathrm{~mL} / \mathrm{min}$, the detection wavelength $(\lambda)$ being set at $300 \mathrm{~nm}$; in Li et al. (2005), methanol:water:acetic acid (19:81:1.5, v/v) was used, flowing at $1.0 \mathrm{~mL} / \mathrm{min}$, with $\lambda$ at $240 \mathrm{~nm}$, and in Pellati et al. (2005), aqueous phosphoric acid solution $(0.1 \%)$ and acetonitrile $(90: 10 \mathrm{v} / \mathrm{v})$, flowing at $1.5 \mathrm{~mL} / \mathrm{min}$, with the detector at $330 \mathrm{~nm}$. Another method, for the simultaneous determination of CGA, CFA and CAF (caffeine), used a linear gradient, the mobile phase changing from $100 \%$ solvent $\mathrm{A}$ (water:acetic acid, $95: 5$ ) to $100 \%$ solvent B (methanol:acetic acid, 95:5) over a period of $65 \mathrm{~min}$ at a flow rate of $1 \mathrm{~mL} / \mathrm{min}$ (Variyar et al., 2003). In the present study we tested a new mobile phase and included a separate detection wavelength for caffeine, because of its important biological activity, based on its absorption spectrum to improve the sensitivity of the method. We also completed the analysis in a shorter time, compared to previously published methods.

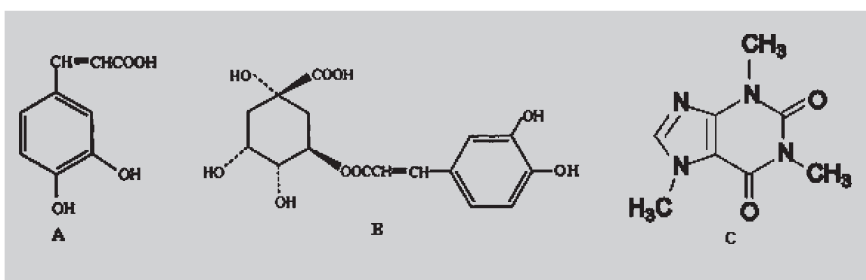

FIGURE 1 - Molecular structures of(A) caffeic acid (CFA), (B) chlorogenic acid (CGA) and (C) caffeine (CAF).

The antioxidant activity (AOA) of phenolic compounds is determined by their molecular structure and, more specifically, by the position and degree of hydroxylation of the ring structure. AOA is conventionally used to indicate the ability of an antioxidant to scavenge some radicals. Phenolic compounds are typical active oxygen scavengers in foods and have been evaluated by several methods (He, Venant, 2004). One of the tests proposed for the assessment of AOA is $\mathrm{DPPH} \bullet$ free-radical (2,2-diphenyl-1-picrylhydrazyl radical) (Figure 2) colorimetry (Brand-Williams et al., 1995). DPPH• is one of the few stable and commercially available organic nitrogen radicals (Huang et al., 2005).

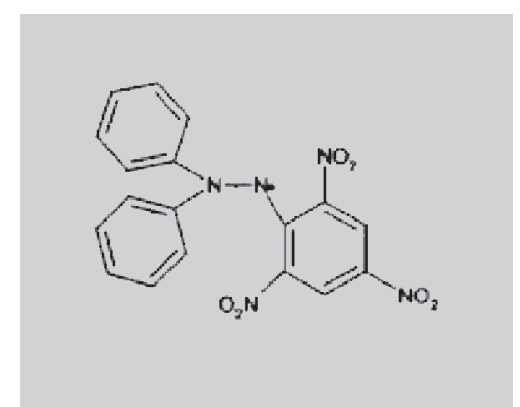

FIGURE 2 - Molecular structure of 2,2-diphenyl-1picrylhydrazyl radical (DPPH•).

The color of $\mathrm{DPPH} \bullet$ changes from purple to yellow in the presence of antioxidants. This reduction is measured by the decrease in absorbance at $517 \mathrm{~nm}$, using visible spectrophotometry. Hence, the effective concentration of antioxidants able to scavenge $50 \%$ of the DPPH $\bullet$ radical $\left(\mathrm{EC}_{50}\right)$ can be calculated.

In the present study we determined the antioxidant capacity of two samples of yerba mate tea purchased from local supermarkets and a sample of powdered dried leaves (industrial residue) and we also determined the antioxidant capacity of chlorogenic acid (CGA), caffeic acid (CFA) and caffeine (CAF), to study how these compounds contribute to the antioxidant activity of the whole extract (synergic or additive effect).

\section{MATERIAL AND METHODS}

\section{Reagents and materials}

Chlorogenic acid (CGA), caffeic acid (CFA), caffeine (CAF), metaphosphoric acid, $\alpha$-tocopherol and $\mathrm{DPPH} \bullet$ (2,2-diphenyl-1-picrylhydrazyl radical) were from Sigma - Aldrich (St. Louis, MO, USA). Ethanol Lichrosolv, acetonitrile Lichrosolv and methanol p.a. were from Merck (Darmstadt, Germany). Yerba mate was obtained in the form of two different commercial teas (Gaúcho and Fontana PN1, both Moinhos Unidos Brasil Mate S.A., Curitiba, PR, Brasil) and as leaf powder (residual tea dust from factory) donated by Leão jr S/A (Curitiba, PR, Brasil).

\section{Chromatographic system}

The chromatographic separation was carried out on a system consisting of two Constametric Pumps, models 3500 and 3200 (Fremont, CA, USA), a Rheodyne 7161 (Contati, CA, USA) manual injector equipped with a $20 \mu \mathrm{L}$ loop and a UV Lab Alliance Model 525 Detector (San Jose, CA, USA). The signal produced was transmitted to a Data 
Jet Thermo Separation Products (San Jose, CA, USA) integrator. The separation was achieved on a $10 \mu \mathrm{m}$ Phenomenex C18 column (Torrance, CA, USA).

\section{Chromatographic conditions}

As several techniques using different mobile phases have been proposed for the simultaneous determination of chlorogenic acid and caffeic acid by HPLC, we had to evaluate them to define a mobile phase composition giving satisfactory specificity for each compound. We also intended to include caffeine in this simultaneous estimation.

We evaluated the following mobile phases: methanol:0.2 mol/L acetate buffer, $\mathrm{pH} 3.6,(15: 85 \mathrm{v} / \mathrm{v})$ with detection at $300 \mathrm{~nm}$; methanol:water:acetic acid $(19: 81: 1.5 \mathrm{v} / \mathrm{v})$ with detection at $240 \mathrm{~nm} ; 0.2 \%$ aqueous metaphosphoric acid solution:acetonitrile $(90: 10 \mathrm{v} / \mathrm{v})$ with detection at $330 \mathrm{~nm}$ and $0.2 \%$ aqueous metaphosphoric acid solution:acetonitrile $(90: 20 \mathrm{v} / \mathrm{v})$ with detection at $330 \mathrm{~nm}$. Each of these mobile phases was maintained at room temperature, flowing at $1.0 \mathrm{~mL} / \mathrm{min}$. The best separation was achieved with the last set of conditions, but for caffeine detection, $\lambda$ was at $275 \mathrm{~nm}$.

\section{Preparation of standard solutions}

Hydroalcoholic standard solutions (in $1: 1 \mathrm{v} / \mathrm{v}$ water:ethanol) were prepared at concentrations $0.49,0.98$, $1.9,3.9$ and $7.8 \mu \mathrm{g} / \mathrm{mL}$ for CGA; at $0.25,0.49,0.98,1.9$ and $3.9 \mu \mathrm{g} / \mathrm{mL}$ for CFA and at $0.244,0.49,0.98,1.9,3.9$ and $7.8 \mu \mathrm{g} / \mathrm{mL}$ for CAF. These solutions were filtered through a $0.22 \mu \mathrm{m}$ membrane and injected into the chromatographic system.

\section{Sample preparation}

The commercial tea samples were finely ground. The resulting powder and the residual tea dust were each sifted on a 40-mesh sieve and then extracted by percolating with ethanol:water $(1: 1 \mathrm{v} / \mathrm{v})$. The ethanol was removed with a rotary evaporator $\left(\sim 45^{\circ} \mathrm{C}\right)$ and the aqueous residue lyophilized in an Edwards do Brasil lyophilizer (São Paulo, SP, Brasil). The dried residue was then taken up in ethanol:water $(1: 1 \mathrm{v} / \mathrm{v})$, to a concentration of $31.25 \mu \mathrm{g} / \mathrm{mL}$, and filtered through a $0.22 \mu \mathrm{m}$ filter membrane. The final filtrate was analyzed in the chromatographic system.

An aqueous extract of the tea dust was also prepared: $2.7 \mathrm{~g}$ of the sample was weighed and $250 \mathrm{~mL}$ of boiling water was added and left for 10 minutes. The aqueous infusion was lyophilized and the dried residue redissolved in ethanol:water, filtered and injected into the chromatograph, exactly as described above for the hydroalcoholic extract.

\section{Antioxidant activity determination}

The AOA of Ilex paraguariensis extracts was measured in terms of hydrogen-donating or radicalscavenging ability, using the stable radical, DPPH $.3 \mathrm{~mL}$ of methanolic solution (Hvattum et al., 2004) of DPPH• $\left(4 \times 10^{-6} \mathrm{~mol} / \mathrm{L}\right)$ were added to $1 \mathrm{~mL}$ of sample at various concentrations $(4.5 ; 6 ; 9 ; 12 ; 15 \mu \mathrm{g} / \mathrm{mL}$ for extracts and standards CAF and CFA; $1.5 ; 3 ; 4.5 ; 6 ; 9 \mu \mathrm{g} / \mathrm{mL}$ for CGA), dissolved in methanol. The decrease in absorbance at 517 nm was determined after 2 hours in darkness in an Incibrás MF 200 spectrophotometer (zeroed on pure methanol). Data were analyzed statistically by factorial analysis of variance (ANOVA), using Graph Pad Prisma 4.

\section{RESULTS AND DISCUSSION}

\section{Simultaneous determination of chlorogenic acid, caffeic acid and caffeine in hydroalcoholic and aqueous extracts of Ilex paraguariensis}

\section{Selection of detection wavelength ( $\lambda$ )}

To improve the detection sensitivity we first determined the $\lambda_{\text {max }}$ for each compound by recording the UV spectra of solutions of chlorogenic acid, caffeic acid and caffeine. The compounds were dissolved in ethanol:water $(1: 1 \mathrm{v} / \mathrm{v})$ to $15.6 \mu \mathrm{g} / \mathrm{mL}$ and scanned in a Hitachi U-3210 (Tokyo, Japan) spectrophotometer (200-400 nm).

It was found that CGA and CFA have absorption maxima at $330 \mathrm{~nm}$, and CAF at $275 \mathrm{~nm}$, so these wavelengths were chosen for optimal measurement of the phenolic compounds.

\section{Selection of the Mobile Phase}

When the first mobile phase, methanol: $0.2 \mathrm{~mol} / \mathrm{L}$ acetate buffer, pH $3.6(15: 85 \mathrm{v} / \mathrm{v})$, was used and column output monitored at $\lambda=300 \mathrm{~nm}$ (Li et al., 2004), some material was retained on the column and the retention time exceeded $70 \mathrm{~min}$. With methanol:water:acetic acid $(19: 81: 1.5 \mathrm{v} / \mathrm{v})$ and $\lambda=240 \mathrm{~nm}($ Li et al., 2005), the retention time exceeded 20 min and the resolution was poor.

With the mobile phase $0.2 \%$ aqueous metaphosphoric acid solution:acetonitrile $(90: 10 \mathrm{v} / \mathrm{v})$ and $\lambda=330 \mathrm{~nm}$ (Pellati et al., 2005), the resolution was good, but the retention time was greater than $25 \mathrm{~min}$. However, when the concentration of acetonitrile was increased to $20 \%$, a retention time of 6 minutes was achieved, as well as good resolution. This mobile phase was therefore adopted, 
with detection at $330 \mathrm{~nm}$ for CGA and CFA and $275 \mathrm{~nm}$ for caffeine.

Figures of merit for caffeine, chlorogenic acid and caffeic acid

The analytical curves for CFA, CGA and CAF were established from the HPLC output for standard solutions (Figure $3 \mathrm{~A} 1$ and A2), 8 replicates (9 for CAF) being performed over 3 days. The regression equations and linear determination coefficients are shown in Table I.

The limits of detection (LOD), quantitation (LOQ), accuracy and precision were calculated as stipulated in the Brazilian guide for the validation of analytical methods (ANVISA, Resolution RE $n^{\circ}$ 899, 05/29/2003).

Limit of quantitation (LOQ) is defined as the smallest amount that can be determined with precision and accuracy acceptable in the experimental conditions established. It was calculated by the equation $\mathbf{L O Q}=\mathbf{S D a} * \mathbf{1 0} / \mathbf{S C}$, where SDa is the standard deviation of the y-intercepts of three analytical curves taken in the vicinity of the limit of quantitation (or blank readings) and SC is the method sensitivity (slope of the analytical curve). The theoretical

TABLE I - Regression equations and determination coefficients for detection of CFA, CGA and CAF

\begin{tabular}{lcc}
\hline Standard & Equation & $\begin{array}{c}\text { Determination } \\
\text { coefficient }\end{array}$ \\
\hline Caffeic acid & $\mathrm{y}=115819 \mathrm{x}-1479.7$ & $\mathrm{R}^{2}=0.9996$ \\
Chlorogenic acid & $\mathrm{y}=61413 \mathrm{x}-148.16$ & $\mathrm{R}^{2}=0.9994$ \\
Caffeine & $\mathrm{y}=59660 \mathrm{x}-600.71$ & $\mathrm{R}^{2}=1$ \\
\hline
\end{tabular}

values were crosschecked by actual analysis of each component into the system under proposed chromatographic system.

Limit of detection is defined as the smallest amount that can be detected but not quantified. It was calculated by the equation $\mathbf{L O D}=\mathrm{SDa} * \mathbf{3} / \mathrm{SC}$.

Accuracy was determined by the equation Accuracy = experimental mean concentration/theoretical concentration.

The LOD and LOQ values are given in Table II.

Content of caffeic acid and chlorogenic acid in the hydroalcoholic extract of Ilex paraguariensis

From the equations in Table I and chromatogram peak areas, the concentrations of chlorogenic acid and caffeine in the hydroalcoholic and aqueous extracts of Ilex paraguariensis were established (Table III). Figure 3 B1-8 shows the chromatograms obtained for the three hydroalcoholic extracts and the aqueous extract of Ilex paraguariensis tea samples. It was not possible do quantify caffeic acid in the extracts, because of its low concentration.

\section{Antioxidant activity of hydroalcoholic and aqueous extracts of Ilex paraguariensis}

The DPPH• radical scavenger activities of the hydroalcoholic and aqueous extracts of Ilex paraguariensis and CGA and $\alpha$-tocopherol standards were assayed at 5 concentrations, as described, with 3 replicates carried out over 3 days, and analytical curves were established. The resulting regression equations and determination coefficients are listed in Table IV.

TABLE II - Limits of detection and quantitation for chlorogenic acid, caffeic acid and caffeine

\begin{tabular}{lccc}
\hline & Caffeic acid $(\mu \mathrm{g} / \mathrm{mL})$ & Chlorogenic acid $(\mu \mathrm{g} / \mathrm{mL})$ & Caffeine $(\mu \mathrm{g} / \mathrm{mL})$ \\
\hline Limit of detection & 0.028 & 0.023 & 0.037 \\
Limit of quantitation & 0.091 & 0.076 & 0.122 \\
Accuracy & $99.72 \%$ & $97.79 \%$ & $99.91 \%$ \\
Precision & $5.76 \%$ & $6.32 \%$ & $7.82 \%$ \\
\hline
\end{tabular}

TABLE III - Concentration of chlorogenic acid and caffeine in hydroalcoholic and aqueous extracts of Ilex paraguariensis tea

\begin{tabular}{lcccc}
\hline Extract & $\begin{array}{c}\text { Concentration of } \\
\text { chlorogenic acid }(\mu \mathrm{g} / \mathrm{mL})\end{array}$ & $\begin{array}{c}\text { Percentage of } \\
\text { chlorogenic acid }\end{array}$ & $\begin{array}{c}\text { Concentration of } \\
\text { caffeine }(\mu \mathrm{g} / \mathrm{mL})\end{array}$ & $\begin{array}{c}\text { Percentage of } \\
\text { caffeine }\end{array}$ \\
\hline Tea dust & $2.60 \pm 0.23$ & $8.33 \pm 0.73 \%$ & $0.90 \pm 0.04$ & $2.88 \pm 0.13 \%$ \\
Fontana leaf & $3.02 \pm 0.02$ & $9.66 \pm 0.05 \%$ & $0.54 \pm 0.07$ & $1.74 \pm 0.23 \%$ \\
Gaúcho leaf & $2.78 \pm 0.06$ & $8.88 \pm 0.19 \%$ & $0.55 \pm 0.03$ & $1.76 \pm 0.10 \%$ \\
Aqueous (tea dust) & $2.53 \pm 0.14$ & $8.09 \pm 0.46 \%$ & $0.94 \pm 0.02$ & $3.01 \pm 0.05 \%$ \\
\hline
\end{tabular}




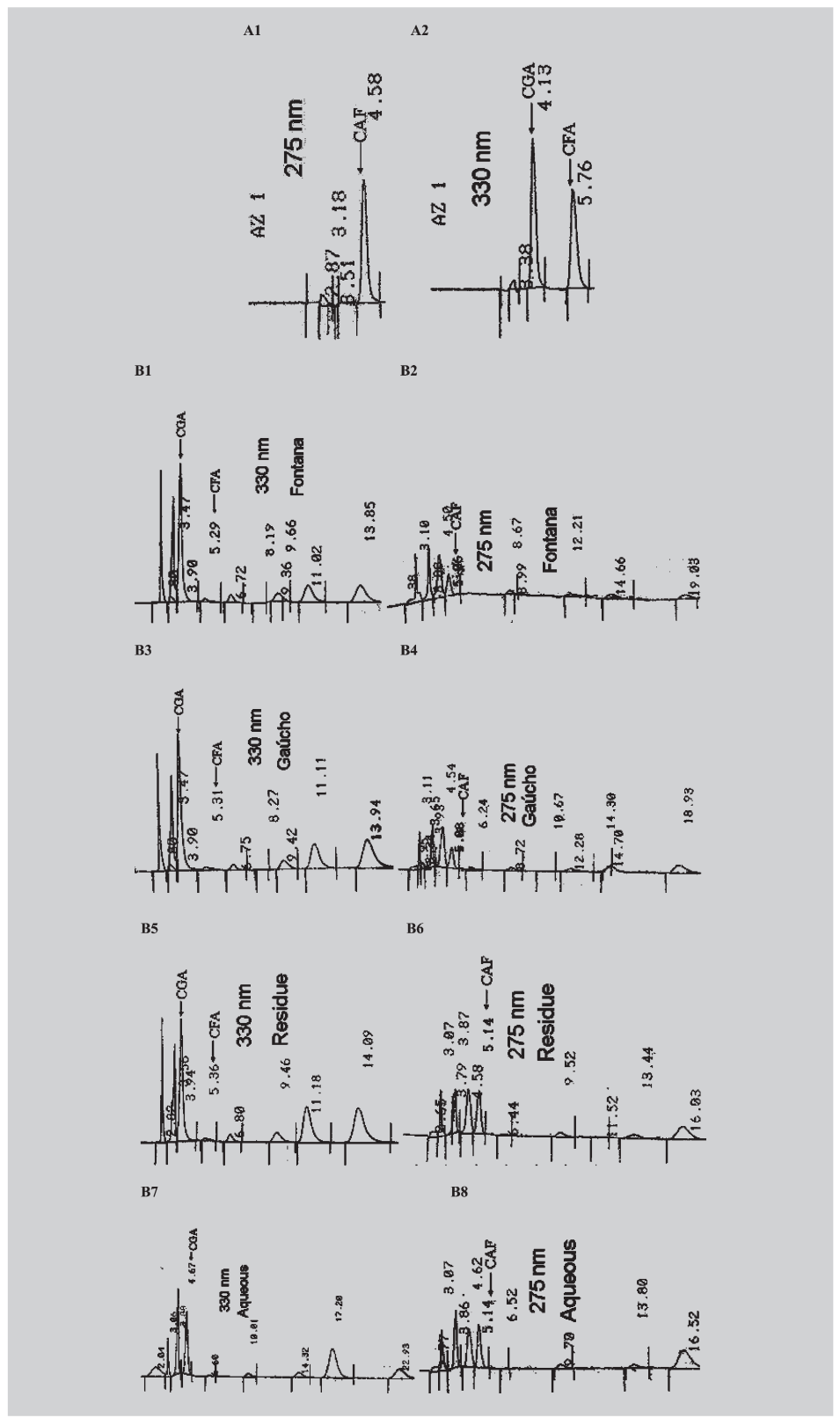

FIGURE 3 - A1 and A2: Chromatograms of caffeine $(275 \mathrm{~nm})$, caffeic acid and chlorogenic acid (330 nm) standards respectively. B1 and B2: Chromatograms of hydroalcoholic extract of Fontana tea at $330 \mathrm{~nm}$ and $275 \mathrm{~nm}$ respectively. B3 and B4: hydroalcoholic extract of Gaúcho tea at $330 \mathrm{~nm}$ and $275 \mathrm{~nm}$ respectively. B5 and B6: hydroalcoholic extract of tea dust at $330 \mathrm{~nm}$ and $275 \mathrm{~nm}$ respectively. B7 and B8: aqueous extract of tea dust at $330 \mathrm{~nm}$ and $275 \mathrm{~nm}$ respectively.

The $\mathrm{EC}_{50}$ values were obtained from the plot of absorbance against concentration for each sample and are summarized in Table V. $\mathrm{EC}_{50}$ is defined as the concentration of antioxidant needed to reduce the initial DPPH• concentration by a factor of two.

\section{CONCLUSIONS}

In the present study of the simultaneous estimation of chlorogenic acid, caffeic acid and caffeine in hydroalcoholic and aqueous extracts of Ilex paraguariesis leaves, and the determination of the antioxidant capacity of these extracts, two brands of yerba mate tea purchased from local supermarkets and a sample of tea dust (factory residue) were analyzed.

The hydroalcoholic and aqueous extracts of Ilex paraguariensis had between $8.09 \%$ and $9.66 \%$ of chlorogenic acid and $1.74 \%-3.01 \%$ of caffeine. Our 
TABLE IV - Regression equations and linear determination coefficients for DPPH • radical scavenger activity in tea samples and standard solutions

\begin{tabular}{lcc}
\hline Sample & Regression equation & Determination coefficient \\
\hline Tea dust & $\mathrm{y}=-0.0133 \mathrm{x}+0.3178$ & $\mathrm{R}^{2}=0.9908$ \\
Gaúcho & $\mathrm{y}=-0.011 \mathrm{x}+0.3215$ & $\mathrm{R}^{2}=0.9922$ \\
Fontana & $\mathrm{y}=-0.0111 \mathrm{x}+0.3248$ & $\mathrm{R}^{2}=0.9985$ \\
$\alpha$-tocopherol & $\mathrm{y}=-0.0117 \mathrm{x}+0.3211$ & $\mathrm{R}^{2}=0.9963$ \\
Aqueous (tea dust) & $\mathrm{y}=-0.0163 \mathrm{x}+0.3152$ & $\mathrm{R}^{2}=0.99$ \\
Chlorogenic acid & $\mathrm{y}=-0.0307 \mathrm{x}+0.3019$ & $\mathrm{R}^{2}=0.9704$ \\
\hline
\end{tabular}

TABLE V - The $\mathrm{EC}_{50}$ values of the various hydroalcoholic and aqueous extracts of $I$. paraguariensis and standard solutions (amount of antioxidant reducing the initial DPPH• concentration by half)

\begin{tabular}{lc}
\hline Sample & $\mathrm{EC}_{50}(\mu \mathrm{g} / \mathrm{mL})$ \\
\hline Tea dust & $11.9 \pm 1.7^{* *}$ \\
Gaúcho & $14.7 \pm 2.2^{* * *}$ \\
Fontana & $15.1 \pm 2.6^{* * *}$ \\
Aqueous (tea dust) & $10.1 \pm 2.1^{* *}$ \\
$\alpha$-tocopherol & $13.6 \pm 0.6^{* * *}$ \\
Chlorogenic acid & $4.6 \pm 0.3$ \\
Caffeine & $\infty^{*}$ \\
Caffeic acid & $0^{*}$ \\
\hline
\end{tabular}

*Caffeine showed no antioxidant activity in the concentrations utilized. Caffeic acid exhibited activity above the expected range $(\mathrm{DPPH} \bullet$ near zero at all CFA concentrations); $* \mathrm{p}<0.05$; $* * \mathrm{p}<0.01 ; * * * \mathrm{p}<0.001$ compared to chlorogenic acid; " $p<0.05$ compared to Fontana.

method for the simultaneous determination of chlorogenic acid, caffeic acid and caffeine proved highly sensitive, the limits of detection and quantitation being lower than in similar methods published elsewhere (Pellati et al., 2005, Li et al., 2004, Potard et al., 1999) and the retention time was about 5 minutes.

This study also showed that both yerba mate commercial leaf and residual tea dust had antioxidant activity comparable with $\alpha$-tocopherol in the same conditions. Further investigation is necessary to establish all the antioxidant compounds present in mate extracts.

As could be foreseen from its molecular structure (absence of hydrogen-donating groups), caffeine did not show any AOA. While not having significant antioxidant capacity, caffeine possesses other important biological properties, such as stimulating effects on the nervous, bilesecreting and cardiovascular systems (Simões et al., 2001), that fully justify its simultaneous determination with the other compounds. We did not find an appreciable concentration of caffeic acid in the extracts, so chlorogenic acid was responsible for part of the observed AOA of the extracts. However, the antioxidant potential of chlorogenic acid was lower than that of the I. paraguariensis extracts. The content of CGA in the extracts was approximately $10 \%$, so we would expect an $\mathrm{EC}_{50}$ value for the extracts 10 times lower than for CGA, if all antioxidant capacity were caused by chlorogenic acid. There must be an additive or synergic effect with other compounds. However, further studies are needed to evaluate other compounds (probably polyphenolics such as 3,5- and 4,5-dicaffeoylquinic acid). Rutin, quercetin and kaempferol are also present in the extract, as they can be identified from chromatograms, but their concentration is too low to contribute effectively to its antioxidant capacity (Filip et al., 2001).

The data presented in this work will contribute to the quality control of Ilex paraguariensis extracts, and thus to improving the quality of cosmetics and pharmaceuticals that employ these extracts as ingredients.

\section{ACKNOWLEDGEMENTS}

We would like to thank Prof. Paulo Chanel for the sample of tea dust and Centroflora Group Brazil for the caffeine standard. This work was supported by a scientific training fellowship from CNPq awarded to Diogo Pineda Rivelli.

\section{RESUMO}

Determinação simultânea de ácido clorogênico, ácido caféico e cafeína, no extrato aquoso e hidroalcoólico de Ilex paraguariensis por CLAE e correlação com a capacidade antioxidante dos extratos por redução do DPPH•

Um novo método de cromatografia líquida de alta eficiência foi desenvolvido para a determinação simultânea de 
ácido clorogênico, ácido caféico e cafeína no extrato hidroalcoólico e aquoso de Ilex paraguariensis. As curvas de calibração mostraram boa regressão linear nas faixas de concentração 0,49-7,8 $\mu \mathrm{g} / \mathrm{mL}$ para o ácido clorogênico, 0,25-3,9 $\mu \mathrm{g} / \mathrm{mL}$ para ácido caféico e 0,244$7,8 \mu \mathrm{g} / \mathrm{mL}$ para cafeína. A redução do radical DPPH $\bullet$ foi usada para determinar a capacidade antioxidante dos extratos. Nosso método para a determinação simultânea de ácido caféico, ácido clorogênico e cafeína foi altamente sensivel, possuindo limites de detecção e de quantificação menores do que em outros trabalhos que empregaram metodologias semelhantes.

UNITERMOS: Ácido clorogênico. Ácido cafeico. Cafeína. Antioxidante. DPPH $\bullet$. Ilex paraguariensis.

\section{REFERENCES}

BRAND-WILLIAMS, W.; CUVELIER, M.E.; BERSET, C. Use of a free radical method to evaluate antioxidant activity. Lebensm. -Wiss. Technol., v.28, p.25-30, 1995.

BRASIL. Resolução RE n.899, de 29 de maio de 2003. A ANVISA - Agência Nacional de Vigilância Sanitária determina a publicação do "Guia para validação de métodos analíticos e bioanalíticos". Diário Oficial da União, Brasília, 2 jun. 2003. Seção 1, p.56-59.

CHANDRA, S.; MEJIA, E.G. Polyphenolic compounds, antioxidant capacity, and quinone reductase activity of an aqueous extract of Ardisia compressa in comparison to mate (Ilex paraguariensis) and green (Camellia sinensis) teas. J. Agric. Food Chem., v.52, p.3583-3589, 2004.

DAY, A.J.; ROTHWELL, A.J.; MORGAN, M.R.A. Characterization of polyphenol metabolites. In: BAO, Y.; FENWICK, R., (Ed.). Phytochemicals in health and disease. 1.ed. New York: Marcel Dekker, Inc., 2004. cap. 3, p.57-76.

DE GROOT, H.; NOLL, T. The role of physiological oxygen partial pressures in lipid peroxidation. Theoretical considerations and experimental evidence. Chem. Phys. Lipids, v.44, n.2-4, p.209-226, 1987.

FILIP, R.; LÓPEZ, P.; GIBERTI, G.; COUSSIO, J.; FERRARO, G. Phenolic compounds in seven South American Ilex species. Fitoterapia, v. 72, p.774-778, 2001.
GUGLIUCCI, A. Antioxidant effects of Ilex Paraguariensis: induction of decreased oxidability of human LDL in vivo. Biochem. Biophys. Res. Commun., v.224, p.338-344, 1996.

GUGLIUCCI, A.; STAHL, A.J.C. Low density lipoprotein oxidation is inhibited by extracts of Ilex paraguariensis. Biochem. Mol. Biol. Int., v.35, p.47-56, 1995.

HALLIWELL, B.; GUTTERIDGE, J.M.C. Free radicals in biology and medicine. 3.ed. New York: Oxford University Press, 1999. p.23.

HE, Q.; VENANT, N.Antioxidant power of phytochemicals from Psidium guajava leaf. J. Zhejiang Univ. Sci., v.5, n.6, p.676-683, 2004.

HUANG, D.; OU, B.; PRIOR, R.L. The chemistry behind antioxidant capacity assays. J. Agric. Food Chem., v.53, p.1841-1856, 2005.

HVATTUM, E.; STENSTROM, Y.; EKEBERG, D. Study of the reaction products of flavonols with 2,2-diphenyl-1picrylhydrazyl using liquid chromatography coupled with negative electrospray ionization tandem mass spectrometry. J. Mass Spectrom., v.39, p.1570-1581, 2004.

LI, H.; CHEN, B.; YAO, S. Application of ultrasonic technique for extracting chlorogenic acid from Eucommia ulmodies Oliv. (E. ulmodies). Ultrason. Sonochem., v.12, p.395-300, 2005.

LI, X.P., YU, J., LUO, J.Y., LI, H.S., HAN, F.J., CHEN, X.G., HU, Z.D. Simultaneous determination of chlorogenic acid, caffeic acid, ferulic acid, protocatechuic acid and protocatechuic aldehyde in chinese herbal preparation by RP-HPLC. Chem. Pharm. Bull., v.52, n.10, p.1251-1254, 2004.

PELLATI, F.; BENVENUTI, S.; MELEGARI, M.; LASSEGNI, T. Variability in the composition of antioxidant compounds in Echinacea Species by HPLC. Phytochem. Anal., v.16, p.77-85, 2005.

POTARD, G.; LAUGEL, C.; BAILLET, A.; SCHAEFER, H.; MARTY, J.-P. Quantitative HPLC analisys of sunscreen and caffeine during in vitro percutaneous penetration studies. Int. J. Pharm., v.189, p.249-260, 1999. 
SCHINELLA, G.R.; TROIANI, G.; DÁVILA, V.; BUSCHIAZZO, P.M. de; TOURNIER, H.A. Antioxidant effects of an aqueous extract of Ilex paraguariensis. Biochem. Biophys. Res. Commun., v.269, p.357-360, 2000.

SIMÕES, C.M.O.; SCHENKEL, E.P.; GOSMANN, G.; MELLO, J.C.P.; MENTZ, L.A.; PETROVICK, P.R. Farmacognosia da planta ao medicamento. 5.ed. Porto Alegre/Florianópolis: Editora da UFSC/Editora da Universidade-UFRGS, 2003. 1104p.
VARIYAR, P.S.; AHMED, R.; BHAT, R.; NIYAS, Z.; SHARMA, A., Flavoring components of raw monsooned arabica coffee and their changes during radiation processing. J. Agric. Food Chem., v.51, n.27, p.79457950, 2003.

Recebido para publicação em 11 de agosto de 2006. Aceito para publicação em 04 de janeiro de 2007. 